\title{
SAMYOGAPRTHAKTVANY $\bar{A} Y A$
}

- as a basis of the theory of mokșa-

\section{Haruo Kurata}

Principles of ritual interpretation embodied in the Mĩmāmsāsūtra (MS) are often applied to the philosophical arguments by later writers of the Mīmāṃsā school. Samyogaprthaktvanyaya (the principle of "distinctness of connection") 1) is one of those principles and applied to the argument about how to attain mokșa (final release)2); some philosophers of the Vedānta school also make use of this principle. The present writer's intention in this paper is to compare the ways of application in the two schools.

(1) The term "samyogaprthaktva" (distinctness of connection) appears in MS IV, 3, 5: "ekasyobhayatve samyogaprthaktvam" which would mean "In a case where one and the same thing is both (obligatory as well as contingent, or optional), there is distnctness of connection (which is a reason for the same thing used at two cases)." According to the commentary by Śabarasvāmin (c. $550 \mathrm{AD}$ ), we would be able to explain the meaning of this aphorism as follows: there are two vedic sentences enjoining the use of dadhi (curds) in Agnihotra; one is "dadhna juhoti" (He sffers oblation with curds.) and the other is " $d a$ dhnendriyakamasya juhuyāt3)" (He shall make oblation with curds for one who is desirous of efficient sense-organs.) The former enjoins dadhi as kratvartha (that which subserves the purposes of action), i. e. what is used for the purpose of establishing Agnihotra; the latter enjoins it as puruṣartha (that which subserves the purposes of man), i. e. what is used for the purpose of obtaining a result. In other words, the former shows the connection of the subsidiary, dadhi, with the principal, Agnihotra; the latter shows the connection of the subsidiary, dadhi, with the principal, the result. Thus one and the same thing, dadhi, is used for two purposes without any difficulty4).

(2) According to the school of Kumārila (c. 650-700 AD) mokșa is the ces- 
sation of bondage, or the dissappearance of the relation between $\bar{A}$ tman and the phenomenal world5). As the phenomenal world, conjuncting with the human body, restrains the man, it is the way to mokșa to make Ātman not enter a new body after the present one falls ${ }^{6)}$. We find an interesting passage which clearly shows Kumārila's standpoint in the Taittirīyopaniṣadbhäṣyavārttika (TUpBhV) of Sureśvara (c. 720-770 AD), a disciple of Śankara:

A person who is desirous of mokșa should not perform niṣiddhakarman (forbidden action) as well as kämyakarman (action prompted by the motive for fruits), (but) he should perform nityakarman (obligatory action) and naimittikakarman (occasional action) with the desire of destroying sin. Thus the soi-disant Mīmāmsakas, rejecting atmajñana (knowledge of Ātman), speak of karman as the means to mokșa7).

Kumārila's view would be that if one performs kamyakarman, he will get abhyudaya (good result), and if he commits niṣiddhakarman, he will get pratya$v \bar{a} y a$ (bad result or $\sin$ ); as both abhyudaya and pratyavāya, if once arised, must be experienced, they require a future body after the present one falls; that is, kämyakarman and nișiddhakarman have no ability to extinct samsära (transmigration), but they become means to renewing bondage; on the other hand, if one performs nityakarman and naimittikakarman, he can eradicate past $\sin ^{8}$ and avoid pratyavãya which should spring up if they are not performed $^{9)}$; then, he will attain the state of mokșa at the moment his body falls, because there is no cause that helps his taking on a new body ${ }^{10}$ ).

Thus Kumārila attaches much importance to karman, but, in fact, he does not neglect $j \tilde{n} a \bar{n} a$. Though he declares, in his Slokavärttika, that atmajñanna cannot be a means to mokșa ${ }^{11)}$, he applies samyogaprthaktvanyãya, in his Tantravärttika, to dividing ātmajñana into kratvartha and puruṣärtha ${ }^{12)}$.

Pārthasārathimiśra (c. $950 \mathrm{AD})^{13)}$, following Kumārila, insists that ätmajñanna is told in two ways in Upaniṣads; that is, it is shown by "avināśi va are'yam atma ${ }^{14) " ~(L o ! ~ T h i s ~ A ̄ t m a n ~ i s ~ i n d e s t r u c t i b l e .) ~ a n d ~ o t h e r ~ s e n t e n c e s ~ a s ~ v i v e k a j n ̃ a n a ~}{ }^{15)}$ (knowledge of the difference of Atman from the human body) which subserves the purposes of action and the function of which as the means to moksa is refuted by Kumārila, and it is shown by "ätmānam upāsīta16)" (Meditate on Ātman.) and other sentences as upāsana ${ }^{17)}$ which subserves the purposes of man ${ }^{18)}$, i. e. 
abhyudaya ${ }^{19)}$ and mokșa $a^{20)}$ as alternatives.

From the facts mentioned above, we may well state that samyogaprthaktvanyāya is applied to dividing ătmajñana into two kinds and to allowing one of them, upāsana, to have abhyudaya and mokșa as its results, and that the theory of practice held by Kumārila and Pārthasārathimiśra is one kind of jñānakarmasamuccayavāda $a^{21)}$, the opinion that jñana must be combined with the performance of karman in order to attain moksa, which is affirmed by Someśvara $^{22)}$ (c. $1200 \mathrm{AD}$ ) and Gāgā-bhatța ${ }^{23)}$ (c. 1630-1700 AD).

(3) In the philosophical system of Śankara constructed in his Upadeśasahasr $\bar{i}^{24)}$, mokșa is the cessation of avidya (nescience) and the means to it is nothing but knowledge of Brahman or the identity of Átman with Brahman ${ }^{25}$. Therefore karman which has avidya as its cause ${ }^{26)}$ cannot be the means to mokșa. Thus Śankkara propagates the path of knowledge ${ }^{27)}$ and attaches importance to the life of mendicant, which, he says, is the best way of life to get jñana ${ }^{28)}$. In the Brahmasūtra (BS), however, the eclectic attitude of the author is clearly found on this point to accept the value of karman ${ }^{29)}$. Then commenting it, Śankara gives a place to karman as the purifier of the mind and remote means to $m o k s a^{30)}$, provided that it is performed without any motive for fruits ${ }^{31}$.

On the other hand, the author of the BS tells us the necessity of the performance of karman for them who do not desire to be liberated and, therefore, do not require jñana, because of the presense of the scriptural passages enjoining it for the purpose of accomplishment of the duty of āśrama ${ }^{32)}$ (life stage); Sankara follows this view. Then karman would be overburdened to bring forth the two results. But the two are not brought about at the same time, so when karman becomes the means to one of them, it cannot be the means to the other. It is to settle this problem that Śankara applies samyogaprthaktvanya $y a^{33}$. He explains that there is no difficulty, because the sentence "yãvajjivam agnihotram juhoti34)" (One performs Agnihotra as long as he lives.) shows karman, Agnihotra in this case, to be performed as an indespensable duty of āśra$m a$; and the sentence "tam etam vedānuvacanena brähmanā vividișanti yajñena dānena tapasānāśakena" (Brahmins desire to know it, this one, i. e. Ätman, through the study of the Veda, sacrifice, charity, and austerity consisting in a dispassio. 
nate enjoyment of sense-objects.) ${ }^{35)}$ shows nityakarman as a means to attain $j \tilde{n} a-$ $n a$, as it eradicates performer's $\sin ^{36)}$, purifies his mind ${ }^{37)}$, and produces vividișa (desire to know) in his heart ${ }^{38}$ ). In other words, the former shows the connection of karman with äśrama, and the latter shows its connection with jñana which is the direct means to mokșa.

Though Śankara tells kämyakarman is not the means to mokșa ${ }^{39)}$, Sureśvara ${ }^{40)}$ makes use of samyogaprthaktvanyāya to his insistence that not only nityakarman but also kāmyakarman, if performed without any motive for fruits, purifies the mind of the performer and makes him embrace vividișa, so karmans as a whole told in the karmakaṇ̃a of the Veda becomes the aid to $j \tilde{n} \bar{a} n a$ told in the jñanakānda, and there should be a connection between the two kāndas.

Other philosopers such as Maṇḍanamiśra ${ }^{41)}$ and Rāmānuja42) also refer to samyogaprthaktvanyāya in their works like Śankkara and Sureśvara.

(4) In conclusion, We may well assume that samyogaprthaktvanyāya is applied to placement of jñana in the theory of mokṣa in the Mimmāmsā school and to that of karman in the Vedānta school.

1) The term samyogaprthaktva as a compound word must be șașthi tatpurusa. See the expression "samyogasya prthaktvatah" found in Mādhava, Jaiminìyanyayyamãa ă (JNM) ad MS IV, 3, 5-7, ĀnSS 24, (Poona 1917), p. 120; Sureśvara, Brhadāranyakopanișadbhāṣyavārttika (BṛupBhV), v. 322, ĀnSS 16, (Poona 1937), p. 112. G. Jha's translation "conjunction and disjunction" would not be acceptable.

2) Mimanmsakas, striving to establish the authority of the Veda, pursue the ideal of dharma. They insist that it is not God but apurva, a potency produced after the performance of karman, that gives a result to the performer. (See BS III, 2, 40 ; MS IX, 1,4-5; 6-10.) We cannot find the attitude to make light of abhyudaya as a thing in samsāra in the Mīmāmsā literature of the early stage. Kumārila, however, advocated his own theory of mokșa while he expounded his theory of interpretation of vedic texts enjoining rituals. See Slokavārttika, Chapter of Sambaindhäkșepaparihāra (ŚV), vv. 101-111, ChSS 3, pp. 668-672.

3) Taittirìya Brāhmaña II, 1, 5, 6 .

4) Cf. Bṛhatī ad MS IV, 3,5-7 (Madras 1964), p. 1027: dadhnā juhotīti homārtha evāyam viniyogah. dadhnendriyakāmasyety eva purușārthah̆; Jaiminīyanyāyamālāvistara (JNMV)ad MS IV, 3,5-7; ekasyāpi dadhno vākyadvayena nityatvam kāmyatvam aviruddham. Śabarasvāmin presents another example, i. e. khadira wood (acacia catechu) used as a yūpavrkșa in the Agnīsomīya rite: the sentence "khādire badhnāti" shows it as kratvartha and the sentence "khädiram vīryakāmasya yüpam kuryat" shows it as purușārtha, We find the term samyogaprthaktva used in MS $\mathrm{XII}, 4,13$, too, where it is mentioned that satyavacana shown by the sentence "satyam brüyāt (or vada)" to be told by a guru at upanayana is purușadharma 
and that shown by the sentence "nānrtam vadet" (Taittiriya Sam̧itā II, 5, 5, 6) in the prakaraña of Darśapürnamãsa is kratudharma. Cf. MS III, 4, 13, Sädhubhäșananiyama also brings forth two results, according to Kumārila. Cf. Tantravarttika (TV), ÂnSS 97 (Poona 1970), pp. 221ff. For the definition of kratvartha and purușärtha, see JNMV ad MS IV, 1,2: kratusvarüpapaușkalyäyaiva yo vidhīyate sa kratvarthah. puruṣaprītaye vidhīyamānāh purușārthāh.

5) Nyäyaratnäkara (NRK) ad ŚV 106cd: śarïrasambandho bandhah, tadabhāvo mokṣah ; Śāstradīpikā (ŚD), ChSS 188, p. 358: na prapañcavilayo mokṣah, kim tu prapañcasambandhavilayah.

6) NRK ad ŚV 106cd: niṣpannānām dehānām yah pradhvamiāähāvah yaś cānutpannānām prägabhāvah mokṣah. Prābhākaras also have the same opinion. See Prakaranapañcika (Benares 1961), p. 341: atyantikas tu dehocchedo nihsseșadharmadharmaparikșayanibandhano mokșah. For the negative character of mokșa held by Mīmāmsakas, see NRK ad ŚV 107ab: abhāvātmakatve mokșasya nityatä, nānandā tmakatve; Ś p. 370: ye'syāgamāpāyino dharmā buddhisukhaduhkhecchädveșaprayatnadharmādharmasamskārās tān apahāya yad asya svam naijam rüpam jñannaśa'ktisattädravyatvādi tasminn avatișthate.......

7) The first verse is ŚV 110. Kumrila's view seems to be attacked by Śankara(Ś), too. (See Ś ad BS IV, 3, 14.)

8) Cf. Kumārila's Brhațtikāa cited in the Nyayasudhä(NS), ChSS 14, p. 330 : nityanaimittikair eva kurvāno duritakșayam......; TV, p. 228: prattyā́samavarnaniyatāni nityanaimittikakarmāny api pürvakrtaduritakșayārtham akarananimittānāgatapratyavāyaparihārārtham ca kartavyāni; NRK ad ŚV 110.

9) Cf. Mạ̣ḍanamiśra, Vidhiviveka (Vārāṇasī 1978), p. 219 : pratișiddhasya ca niyogato'kartavyasya kriyāyām iva niyogatah kartavyasyākriyāyām pratyavāyo yuktah̆. Mimāmsakas follow the theory of rnatraya. (See Śabara ad MS VI, 2,31.) Neglect of rnatraya constitutes upapätaka (Manu XI, 66-67); if one longs for mokșa without paying rnatraya, he must go to Hell (Manu VI, 37).

10) ŚV 108-109.

11) ŚV $102 \mathrm{~cd}$.

12) TV, p. 227.

13) ŚD, pp. 372-377; NRK ad ŚV 102cd.

14) Bṛhadārạnyaka Upanișad (BṛUp) IV, 5, 14.

15) The view that this jñana is the means to mokșa is attributed to the Sāmkhya system and rejected by Kumārila (ŚV 102: NRK ad ŚV 102).

16) Chāndogya Up (ChUp) VIII, 12,6. Cf. Brụp I, 4,5.

17) upās- means "to know A as B," so the term upāsana is used as a synonim of vidyā, jñāna and other words in Upanișads and the Vedānta literature. It would mean the mental activity to identify one well-known phenomenal object with the supreme being. If one performs sacrifice with upāsana, his sacrifice will be more efficient. See ChUp I, 1,10: yad eva vidyaya karoti......tad eva vĩryavattaram bhavati; Ś ad Bhagavadgītā XII, 3: upāsanam nāma yathāśāstram upāsyārthasya vișayīkaranena sāmīpyam upagamya tiladhārāvat samānapratyayapravāhena dïrghakãlam yad āsanam tad upāsanam äcakșate. jñãna in Bhagavadgĩtā IV. 37 is upãsana (see NRK ad ŚV 110).

18) ŚD, pp. 374-375; NRK ad ŚV 104. Results are found in vākyaśeșa according to 
rātrisatranyāya (MS IV, 3, 17-19). Cf. TV, p. 227; NRK ad ŚV 104.

19) This is shown by the sentence "sarvān kāmān äpnoti" (ChUp VIII, 12, 6; VIII, 7,1 ).

20) This is shown by the sentence "na sa punar avartate" (ChUp VIII, 15, 1).

21) Cf. TV, p. 228: na ca teșām bhinnaprayojanatvād bhinnamārgatvāc ca bādhavikalpaparasparāingāingibhävah sambhavanti.

22) NS, p. 330: avāntarakāryabhedān na bädhavikalpau bhinnamārgatvān nāingāingibhãvah sambhavatĩti päriśeșyāt samuccaya eva yuktah.

23) Bhātțacintāmani, ChSS 6, p. 43: jñānakxrmanoh samuccayena (mokșa-) janakatã.

24) S. Mayeda (ed.), Śañkara's Upadeśasāhasrī (Upad), (Tokyo 1973).

25) Upad I, 1, 6-7.

26) Upad I, 11, 15.

27) Upad I, 16, 68.

28) Upad II, $1,2$.

29) H. Nakamura, Brahmasütra no Tetsugaka (Tokyo 1951), pp. 470-483.

30) $\hat{S}$ ad BS IV, 1, 16; 18. Cf. ChUp I, 1, 10. That karman is the remote means to mokșa is clearly stated by Sureśvara in his Naișkarmyasidḋhi I, 52 .

31) BS III, 4, 27.

32) BS III, 4,32 .

33) $\hat{S}$ ad BS III, 4, 33: karmābhede'pi samyogabhedāt. The term samyogabheda is a synonim of samyogaprthaktva. Cf. ŚD, p. 373.

34) The source is the Bahrrcabrähmana accoding to Śabara ad MS II, 4, 1. Cf. Āpastambaśrautasūtra III, 14, 1.

35) Briup IV, 4, 22.

36) Ś ad TaittiriyaU , upodghāta; $I, 11,4$.

37) Upad I, 17, 22; Ś ad ChUp I, 1, 1; Ś 's padabhāṣya ad Kena Up IV, 8.

38) S ad BS III, 4, 27. But it is only sañcitakarman that is destroied by jñana; prärabdhakarman is stronger than jñana and lasts till the end of the life of the aspirant. (See Ś ad BS IV, 1, 14-15; Ś ad Br Up I, 4, 7.) Ś tells all of traivarnikas are admitted to study jñana (Ś ad BS I, 3,34-38), but that only brahmins are allowed to enter the sannyāsáśrama (Ś ad Brup III, 5, 1); then, kșatriyas and vaiśyas would be able to perform karman to attain jñana while they live in the gṛhasthāśrama. For the same, view held by Rāmānuja, see Śrībhāṣya ad BS III, 4,26: karmavatsu grhastheșu yxjñädinityanaimittikasarvakarmāpekșā vidyā.

39) Ś ad Bṛ̂p IV, 4, 22: vedānuvacanayajñadānatapahśabdena sarvam eva nityam karmopalakṣyate. evam kāmyavarjitam nityam karmajātam sarvam ātmajñānotpattidvārena mokșasādhanatvam pratipadyate.

40) Ānandagiri ad BrupBhV, v. 322 16, ĀnSS 16, pp. 112-113.

41) Brahmasiddhi (Madras 1937), p. 27: samyogaprthaktvena sarvakarmanām evātmajñanāahikārānupraveśam āhuḥ, vividișanti yajñeneti śruteh ; p. 36 : idam tu yuktam ......kāryāntaranirākāànkṣānām karmanām saṃyogaprthaktvāt "tam etam vedānuvacanena brāhman̄ā vividișanti" iti vidyāingabhāvah.

42) Śrībhāsya ad BS III, 4, 33 : agnihoträdīnām iva......viniyogaprthaktvenobhayārtham na virudhyate. The term viniyogaprthaktva is a synonim of samyogaprthaktva. (See Ś ad BS III, 4, 34: yajñādīnām vividișām viniyuñkte.; Bṛhatī ad MS IV, 3, 5-7. See note 5) 